\title{
O CANTO DO CREPÚSCULO REFLEXÕES ORNITO-ANTROPOLÓGICAS SOBRE UM MITO DE ORIGEM KADIWÉU
}

Francesco Romizi

Remanescentes no Brasil dos índios de língua guaicuru, os Kadiwéu da fronteira paraguaia ainda hoje praticam, entre diferentes formas de apreensão do mundo, a mítica. Em particular, como todo ser humano, eles intensificam o exercício do "pensamento selvagem" - como o chamou Lévi-Strauss (2010), para colocá-lo fora da antinomia mentalidade lógica/mentalidade pré-lógica - ao lerem, explicarem e integrarem as realidades e os acontecimentos, sejam estes grandes ou pequenos, que se lhes oferecem aos sentidos, ao raciocínio e aos sentimentos. Contudo, como sabemos, dentro deste marco de continuidade existe uma importante ruptura na vida espiritual deles: séculos e ciclos de evangelização e de contato com o ecalailegi (o "branco" e, mais em geral, o não índio) produziram um cenário religioso complexo e delicado em que se encontram e desencontram, sobrepõem e distanciam, misturam e separam, reconhecem e estranham diferentes sistemas e modos de praticar o pensamento mítico.

Apesar da reflexão aqui apresentada dirigir-se à análise de um mito ameríndio e do pensamento que ele veicula, ela surge no âmbito de uma pesquisa de pós-doutorado que abarcou, ao longo de dois anos e meio, a vida religiosa dos Kadiwéu na complexidade das suas atuais modalidades e expressões. Entre outras coisas, nas nossas estadias na aldeia Alves de Barros, situada no território de Porto Murtinho, Mato Grosso do Sul, tentamos sopesar os efeitos (palavra que poderia, erroneamente, levar a supor uma relação unívoca), no xamanismo local, da intensificação do contato com o cristianismo, que se deu a partir dos anos 1960 com o estabelecimento, no interior da aldeia, de uma igreja batista (guiada pelo pastor Gerhard Kern), seguida por outras denominações pentecostais. Atualmente, são quatro as igrejas evangélicas - todas dirigidas por pastores nativos - que trabalham para despertar e consolidar a fé cristã nos corações dos habitantes de Alves de Barros, cerca de 1.600 pessoas, segundo os últimos levantamentos censitários (Duran 2017:24).

Se as crenças nativas tinham convivido por muitos anos e sem muitos problemas - mas não sem recíprocas influências - com um catolicismo popular, em boa parte conduzido em autogestão pelos próprios Kadiwéu, 
aparentemente a entrada do protestantismo na terra indígena acabou com elas. As missões transculturais evangélicas (Almeida 2006:287) tomaram o campo da moral comunitária, reorganizando seu universo de valores, rituais e comportamentos. Entretanto, se usamos o advérbio de modo "aparentemente" é porque é simplesmente impensável que séculos de práticas e pensamentos místicos tenham sumido num abrir e fechar de olhos. A despeito de certa amnésia generalizada sobre o mundo espiritual de "antigamente" e das muitas histórias ouvidas sobre "o último xamã" e sua entrega, in articulo mortis, à Boa Nova - cuja recorrência não deixava de evocar-nos certa captatio benevolentiae - a realidade com a qual nos deparamos é a de um panorama religioso fluido e intricado que se depreende tanto de uma análise histórico-comparada dos mitos ${ }^{1}$ - sejam "antigos" ou cristãos - como de um exame sincrônico das práticas mágico-religiosas.

O relato aqui destacado não ficou imune ao processo de cristianização do continente, passando por várias transformações (cf. Petschelies 2013), assim como seu tema dominante, o da saída de um buraco da primeira humanidade - que encontramos na mitologia de outros povos chaquenhos, como os Guaná (atuais Terena e Kinikinau), frequentemente "vassalos" dos Guaicuru. Contudo, como anotou Lévi-Strauss (1996:170) em Tristes trópicos, tal mito, "depurado pelos séculos, resplandece com admirável simplicidade". Em particular, parece-nos interessante que, durante pelo menos o último século, se guardou o tema de três pássaros-sentinela, dos quais, como ornitologistas aficionados, os interlocutores kadiwéu indicavam, cada vez com abundância de detalhes, nomes, caraterísticas, alimentação, hábitos etc. Será a estes três pássaros - a coruja, a anhuma e o carão - que o demiurgo Gô-noêno-hôdi pedirá ajuda para descobrir quem está roubando o seu peixe que, dependendo das variantes que temos em nossas mãos, encontra-se no seu lago (Buff Chevalier 1982:2), no jirau² que ele tem num rio (Ribeiro 1979:103; Oberg 1949:63), no seu riacho (Frič 1912:397), na sua lagoa (Frič apud Loukotka 1933:260; Pechincha 1994:110), numa baía (Siqueira Jr. 1993, Anexo 2:9), no próprio buraco onde se ocultavam os ladrões (em depoimento recolhido pessoalmente). Estes últimos, como veremos, são os ancestrais do ser humano. Descobertos graças à ajuda de um dos três pássaros mencionados, eles serão "humanizados" pelo demiurgo, que os separará, entregando-lhes objetos e habilidades culturais específicos. É assim que, segundo a mitologia kadiwéu, tomaram forma as nações que hoje povoam a Terra.

O presente artigo, sem querer calar o campo hodierno, surge do descobrimento, em etnografias passadas e alheias, de duas informações importantes relativas aos pássaros deste mito e até agora desapercebidas. 
Trata-se de duas relações, impressas no esqueleto do mito, mas que podemos facilmente fazer vir à superfície. A primeira relação é a existente entre os três pássaros-detetives convocados pelo demiurgo. Estes, como tentaremos demonstrar na primeira parte do texto, formam uma tríade, composta por dois termos opostos e um termo intermediário. Tratar-se-ia de uma daquelas tríades por meio das quais procede o pensamento do "selvagem", segundo a interpretação estruturalista de Lévi-Strauss (1985:259) que, aliás, nas Mitológicas 1 assumem uma forma bastante parecida com a que estamos aqui interrogando: a das sentinelas negligentes/boa (Lévi-Strauss 2004a:140 e ss.) nos mitos de origem das mulheres (M31 e M32) de outros dois povos chaquenhos.

Esta conjectura inicial é corroborada, ao longo da primeira parte do artigo, graças à ajuda da ornitologia e de incursões pontuais nas características do bioma do Pantanal e do ecossistema da região do Chaco que este integra. Descobriremos que o pássaro carão, aproveitando-se de certas ambiguidades inatas, medeia - no sentido de "retém qualquer coisa de" (Lévi-Strauss 1985:261) - vários termos opostos encarnados pela coruja e pela anhuma; dualidades que distinguem, ordenam e classificam qualidades e relações ecológicas das aves do Pantanal, mas que aludem continuamente a situações, problemas e aptidões características do desempenho kadiwéu naquele mesmo meio. Em linha com o estruturalismo mais clássico, a mediação bio-lógica de uma oposição "natural" ofereceria aos Kadiwéu um instrumento (e um modelo instrumental) para pensar e resolver contradições assumidas como equivalentes, dadas no plano sócio-lógico.

A outra relação, extraída da herança etnográfica kadiwéu, é aquela entre o detetive bom e os ladrões - isto é, entre o carão e os progenitores do ser humano, que ele, único entre os pássaros convocados pelo demiurgo, será capaz de avistar. Esta segunda relação se insere na interação roubado-ladrões - demiurgo "criador"-progenitores do ser humano "criados" - articulando-a e fazendo-a possível. Em nenhum dos escassos estudos que penetraram a mitologia kadiwéu encontramos menção ao fato de que o carão, pássaro investido de humanidade (humanity), reconheceu sua própria condição - "viu uma porção de gente" (Ribeiro 1979:104) - em uma humanidade (humankind) ainda "em estado cru" (Pechincha 1994:110), depois de experimentar um alimento cozido, sendo este último constitutivo, tanto para os Kadiwéu como para os outros povos ameríndios, de sua própria condição humana. Um animal-humano, em suma, que intui a humanidade de uns humanos-animais, comendo o alimento por meio do qual os descendentes destes construirão sua condição humana como radicalmente oposta ao estado daquele (cf. Ingold 1995). 
Esta ocorrência, ilustrada, a dizer a verdade, de uma maneira pouco explícita nas versões coletadas por Darcy Ribeiro (1979:104) e Jaime Siqueira Jr. (1993, Anexo 2:9), é no mínimo bizarra e merece ser interrogada junto às torções de pescoço e de perspectiva que ela nos inflige. Se a relação entre os pássaros-detetives encaixa perfeitamente no modelo estruturalista, acreditamos que a proposta perspectivista, lançada em 1996 por Eduardo Viveiros de Castro e Tânia Stolze Lima, apesar de germinar no campo etnográfico amazônico (povos tupi), poderá nos ajudar a esclarecer o alcance antropológico desta segunda relação, real, interespecífica (lato sensu) e construída pelo "corpo". À continuação, apresentaremos nesta ordem essas relações junto à narrativa que parecem sustentar, para finalmente refletir sobre seu lugar na constituição da armação do pensamento mítico deste povo ameríndio.

\section{Três pássaros-detetives: os dois eixos horizontais}

Gô-noêno-hôdi - figura central da mitologia kadiwéu - no começo dos tempos "só comia peixe, tinha um jirau num rio e os peixes de noite pulavam de qualquer lado das varas, caindo nas palhas do meio do jirau" (Ribeiro 1979:103). Até que começaram a sumir os peixes e Gô-noêno-hôdi, procurando remédio para esta situação prejudicial, mandou seus ajudantes pássaros investigarem. Estes eram: etolitoli, a corujinha; djorranita, a anhuma; e tabona, o carão (Siqueira Jr. 1993, Anexo 2:9). A primeira "ficou cantando até meia-noite e aí dormiu" (:9). Mesmo assim, antes de dispensá-la, Gô-noêno-hôdi lhe deu muitos gafanhotos que tinha juntado para ela. A anhuma também logo adormeceu, e Gô-noêno-hôdi lhe deu comida e a mandou embora. Finalmente, Gô-noêno-hôdi, ansioso por encontrar os ladrões que estavam roubando o seu peixe, chamou o carão, que depois de cantar a noite inteira:

Estava quase amanhecendo e [...] cantou mais diferente: "Pois é, meu Deus, eu já vi muita gente que veio pegar peixe aqui na baía". Ele [Gô-noêno-hôdi] pegou a sandália de couro e calçou e chamou cachorro dele, o cachorro Djacodaga e o outro chamava Oadchoedaga. Ele levou os cachorros onde eles passaram e tinha um rastro de gente [...]. Aí Djacodaga descobriu uma chapinha de barro tampando um buraco e o cachorro cheirou assim e bateram em seu nariz e o cachorro gritou. Deus foi lá ver [...]. Ele viu a chapa de barro tampando o buraco e ergueu aquela tampa e, quando jogou fora, viu que tinha todos os tamanhos de rosto de gente, tinha muita gente naquele buraco (Siqueira Jr 1993, Anexo 2:9-10).

É neste momento que Gô-noêno-hôdi se torna o Deus criador ou, mais precisamente, o demiurgo transformador, já que, além de não receber culto 
algum, atua num cenário cosmogônico que não descansa sobre a ideia de uma criação ex nihilo (Viveiros de Castro 2004:477). Ele puxa do buraco, um de cada vez, todos os povos, atribuindo-lhes qualidades constitutivas. Entretanto, se o demiurgo é o protagonista inegável desta transformação, ele não poderia tê-la realizado sem a ajuda do carão, que teve a capacidade de ver tal humanidade. É por esta razão que consideramos necessário aprofundar seu lugar no mito. Para fazê-lo, decidimos começar por identificar e analisar, numa ótica comparativa, todos os pássaros convocados por Gô-noêno-hôdi. Estes mudam sensivelmente nas versões do mito recolhidas ao longo dos anos pelos pesquisadores que entraram em contato com os Kadiwéu. Nossa primeira tarefa consistirá em reconhecer propriedades e relações que se mantêm invariantes, para dizê-lo ao modo de Lévi-Strauss, neste grupo de transformações.

Algum tipo de ave strigiforme - ordem de aves de rapina com hábitos predominantemente noturnos - está presente em quase todas as variantes do mito. Ribeiro (1979:104), Oberg (1949:63), Siqueira Jr. (1993, Anexo 2:9) e Pechincha (1994:110) usam o termo guaicuru etolitoli, em que os interlocutores do primeiro e da última reconhecem o caburé - que aparece também na versão de Glyn e Cynthia Griffiths (apud Wilbert \& Simoneau 1989:19), missionários-linguistas do SIL (Summer Institute of Linguistics) - e a informante do terceiro, uma "corujinha pequeninha". As informações sobre alimentação e hábitos oferecidas pelas diferentes versões do mito nos levam a identificar a corujinha ou caburé não tanto no caburé propriamente dito (Glaucidium brasilianum), mas sim em outra coruja de pequeno porte da savana pantaneira, a coruja-buraqueira (Athene cunicularia). Com efeito, esta e a do mito compartilham o fato de serem particularmente ativas durante o crepúsculo vespertino e de incluírem, entre seus principais alimentos, os gafanhotos (Ihering 1940:285). O que interessa, está claro, não é identificar com precisão a exata colocação taxonômica de todos os pássaros do mito, mas a sua tipologia mítica, isto é, as qualidades que por meio deles estão sendo realçadas e postas em relação. Realmente, nas variantes do mito, algumas das aves protagonistas mudam, mas sem que se produza uma alteração significativa no âmbito das propriedades e das relações sistêmicas mobilizadas.

Se até agora identificamos uma primeira tipologia ornito-mítica, que a partir deste momento definiremos com o termo genérico de coruja, a segunda classe de sentinela negligente é integrada, essencialmente, por dois pássaros: a anhuma (Anhima cornuta), em Frič (apud Loukotka 1933:260), Ribeiro (1979:103), Buff Chevalier (1982:2), Griffiths (apud Wilbert \& Simoneau 1989:19), Siqueira Jr. (1993, Anexo 2:9) e Pechincha (1994:110); e a tachã (Chauna torquata), conhecida também como anhuma-do-pantanal (Sick 1997:242), em Frič (1912:397). A anhuma e a tachã representam as duas 
espécies brasileiras da Anhimidae, família de aves aquáticas anseriformes - ordem que inclui, na família dos Anatidae, patos, gansos e cisnes. Ambas habitam pântanos, savanas e planícies de inundação de rios associados a florestas úmidas. Segundo Sick (1997:241), os dedos enormes mas desprovidos de membranas natatórias são produto de uma adaptação ao ambiente paludícola, que facilitaria a locomoção sobre as plantas aquáticas. Diversamente das corujinhas vistas anteriormente, as anhumas são aves corpulentas, que chamam a atenção pelo tamanho - "é ave grande, de $85 \mathrm{~cm}$ de comprimento comparável ao peru" (Ihering 1940:86) - pela envergadura (170 cm) e pelo voo pesado e barulhento.

\section{Coruja}

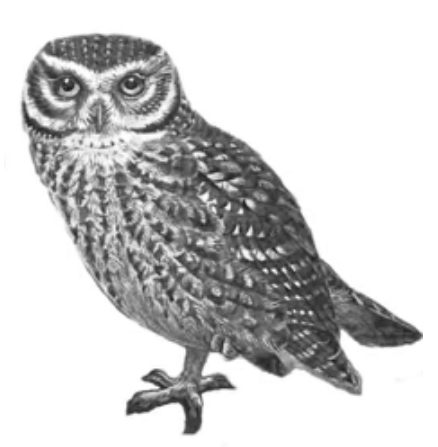

(seg. Naumann 1899, Band V,

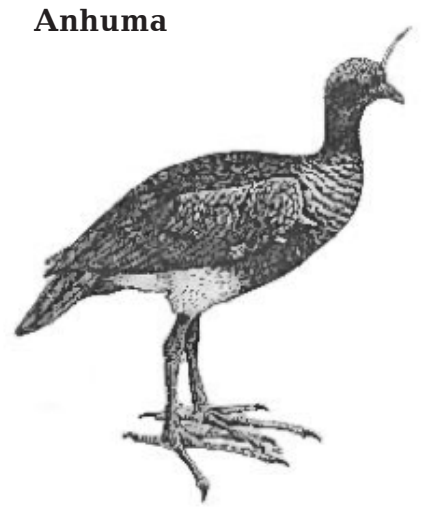

(seg. Ihering 1940:86)

Tafel 2)

\section{Carão}

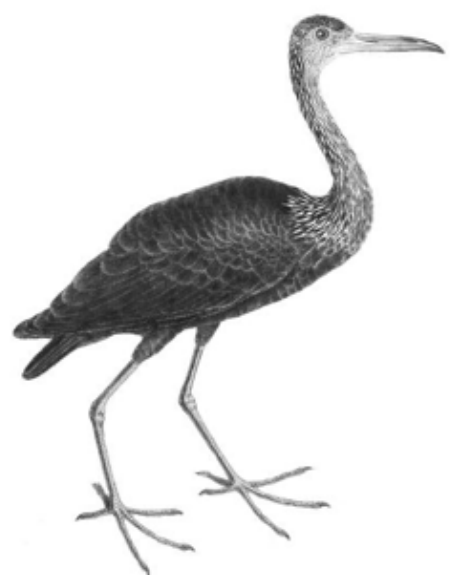

(seg. Martinet 1765, vol. 9:848) 
Uma etapa intermediária no caminho para a compreensão do êxito do carão, terceiro componente da tríade ornito-mítica mobilizada pelo demiurgo, é representada pelo entendimento das razões que levaram este último a convocar a coruja e a anhuma - que se mostraram incapazes de cumprir a tarefa recebida. Tomando emprestadas as palavras de um conhecido trecho de $O$ pensamento selvagem, as aves convocadas por Gô-noêno-hôdi "são consideradas úteis ou interessantes porque são primeiro conhecidas" (Lévi-Strauss 2010:25): as corujas são rastreadoras atentas e sigilosas, caracterizando-se por um voo silencioso, um ouvido excepcional e visão também extraordinária (Sick 1997:396); por seu lado, a anhuma, que costuma descansar pousando na copa das árvores, avisa sobre qualquer presença (:241). Quando, num momento indefinido entre os séculos XIX e XX, o cidadão francês Emilio Rivasseau foi caçar numa lagoa junto com um cacique kadiwéu, ele ficou contente por não ter encontrado uma anhuma, porque elas "certamente teriam lançado o grito de alarme e espantado todos os bichos dos arredores e todos os comensais da lagoinha" (Rivasseau 1941:114).

O fato de ser a coruja um ótimo rastreador e a anhuma uma excelente sentinela esclarece os motivos mais evidentes que levaram Gô-noêno-hôdi a solicitar a sua ajuda, mas não explica a razão do próprio insucesso. Para entender isto, além do êxito do carão, devemos conhecer esta terceira tipologia de ave que aparece no mito, a que finalmente cumpriu a tarefa investigativa. Segundo as informações recolhidas por Frič (1912), Oberg (1949), Ribeiro (1979), Buff Chevalier (1982), Griffiths (apud Wilbert e Simoneau 1989), Siqueira Jr. (1993) e Pechincha (1994), o carão (Aramus guarauna) foi o pássaro que descobriu e delatou os ladrões que estavam roubando o peixe de Gô-noêno-hôdi. Trata-se de uma ave gruiforme bastante grande (mede até $70 \mathrm{~cm}$ de comprimento), tem o corpo pardo-escuro com a garganta branca e riscas da cabeça e do pescoço também brancas (Sick 1997:290).

Haveria um consentimento unânime se não fosse pela segunda versão de Frič (apud Loukotka 1933:260), na qual, em lugar do carão, aparece o íbis, nome comum da subfamília de aves Threskiornithinae, que inclui aves conhecidas como íbis, curicaca ou tresquiórnis. Este desdobramento do carão em íbis, análogo ao da anhuma em tachã, em parte se explica pela semelhança morfológica e de hábitos que existe entre os dois; tanto que, inclusive em textos científicos (Sick 1997:290), aponta-se um parentesco entre o carão e os Threskiornithidae, família de aves pelecaniformes que inclui a subfamília dos íbis. Outra expressão desta relação intercambiável do carão-íbis, dentro da presente tipologia ornito-mítica, é aquela encontrada em um trecho de uma versão resumida deste mesmo mito de origem que nos ofereceu um ancião e líder histórico kadiwéu, em setembro de 2015: “E tem ladrão que 
quer pegar o peixe lá dentro, e tem o passarinho das águas, o curicaca, que quando viu o ladrão, já conta, já grita que o ladrão quer pegar o peixe" (José Marcelino Alves de Barros, 24/09/2015).

A explicação que o mito, em todas as versões, oferece-nos é que esta ave gruiforme pantaneira pôde ver os ladrões quando "estava quase amanhecendo" (Siqueira Jr. 1993, Anexo 2:9) - quando "Eidit-juába (aurora) está próxima a aparecer" (Frič 1912:397) - porque foi a única que ficou acordada até o alvorecer. Isto foi possível, em primeiro lugar, porque, como nos explica a ornitologia (Sick 1997:290), o carão é um pássaro não só noturno, mas também crepuscular, ou seja, ativo naqueles momentos diários de transição, o amanhecer e o anoitecer, em que luz e escuridão se encontram e se fundem, a primeira tornando-se penumbra, a segunda, albor. O curicaca (Theristicus caudatus), apesar de pertencer a outra ordem, partilha com o carão esta caraterística, aqui considerada fundamental, sendo popularmente conhecido como "o despertador do pantanal" (:213). Emblematicamente, a passagem do ser humano da natureza à cultura encontra a sua ambientação neste cenário crepuscular.

Se o objetivo desta primeira parte do mito parece ser o de enfatizar, por meio do êxito do carão nas horas do amanhecer, o valor positivo da ambiguidade - enquanto nexo de articulação entre realidades diferentes ou contrárias (como a natureza e a cultura) - poderíamos pensar que esse valor seja afirmado por meio da interposição estrutural do carão crepuscular, com respeito a uma relação de oposição, cujos polos seriam representados pela notória vida noturna da coruja e a atividade predominantemente diurna da anhuma (Gill; Stokes \& Stokes 1974:46). Contudo, a análise do conteúdo mítico e o estudo destas espécies animais mostram que todas as nossas três tipologias ornito-míticas têm hábitos crepusculares. De certo modo, a mesma crepuscularidade parece constituir um universo conceitual complexo e variegado que se, por um lado, estabelece um plano de congruência entre os três pássaros em questão, por outro, abre-se para novos níveis de diferenciação. A mais perfeita crepuscularidade do carão coloca-o a meio caminho entre a crepuscularidade anunciadora do dia, da anhuma, e à que acompanha o escurecer, da coruja; mas a oposição dia-noite não é a única que o carão atravessa e habita, instalando-se no espaço intersticial das relações diferenciadoras estabelecidas pelo encontro entre a coruja e a anhuma.

Primeiramente, o carão não é nem estranho ao elemento aquático, como a terrícola coruja-buraqueira, nem está continuamente imerso nele, como a anhuma, cuja dieta se baseia em plantas palustres e cujos ninhos flutuantes são ancorados em arbustos na água rasa (Sick 1997:241). Esta caraterística "anfíbia" se revela particularmente útil ao carão em seu desempenho a 
serviço do demiurgo: inicialmente chamado a vigiar o cenário aquático do roubo, abandona-o para seguir os ladrões até o seu refúgio terrestre. Além disso, esta ambiguidade do carão é selada pelo seu alimento, principal motivo de seus passeios aquáticos: qual animal seria mais ecologicamente dúbio do que um invertebrado como o caramujo que, para sobreviver nas mutáveis condições climáticas do seu habitat, desenvolveu um duplo sistema de respiração, aquática e aérea, mediante o emprego de brânquias e de um pulmão?

É precisamente a alimentação do carão que nos leva ao terceiro tipo de ambiguidade desempenhada por esta espécie de pássaro. Como sabemos, a coruja é uma ave de rapina, portanto, carnívora, que se alimenta de insetos terrestres - no mito, os gafanhotos. A anhuma, ao contrário, é herbívora, alimentando-se principalmente de folhas de plantas aquáticas (Sick 1997:241). O carão, com sua alimentação constituída quase exclusivamente por estes grandes caramujos aquáticos chamados aruás (Pomacea) (:290), transcende e atravessa as sobreditas modalidades dietéticas. De fato, se, por um lado, ele come animais, por outro, a conformação cascuda das suas presas e as estratégias tróficas por meio das quais as consome remetem a um tipo de alimentação frugívora.

Entre estas duas últimas oposições, que insistem na ecologia e na alimentação, coloca-se outra, importantíssima na vida dos seres dessa paisagem pantanosa, também inscritível no par anhuma-coruja. Como sabemos, no Pantanal, a chuva divide a vida em dois períodos bem distintos: a estação da seca e a estação das chuvas. Ao seco e úmido Lévi-Strauss dedicou a primeira parte de Do mel às cinzas, Mitológicas 2 - detendo-se de modo particular nos povos do Chaco. Aqui, em mais de uma ocasião (2004b:106, 131), o antropólogo nos lembra como a estação seca é a dos grandes bandos de gafanhotos, isto é, do principal nutrimento da coruja de nosso mito. Inversamente, não podemos deixar de associar as anhumas ao outro grande período do ano, já que elas "emigram quando secam certos braços de rios e lagos que habitam durante as chuvas" (Sick 1997:242).

O carão, analogamente a estas últimas, protagoniza migrações de caráter regional atrás da água (e do seu alimento). No entanto, um depoimento que encontramos na obra que Pastor Arenas e Gustavo Porini (2009:53, 176) dedicam às aves na vida dos Toba - outro povo chaquenho da família linguística guaicuru - nos faz refletir. Segundo este, quando o carão "canta, atrás dele (vem) a água, adiante (está) ainda seco". Ou seja, ele anteciparia e anunciaria o aumento do caudal do rio. Isto significa que o carão, além da oposição diurno/noturno, medeia também aquela entre as duas estações? Consideradas suas virtudes "anfíbias", nos parece mais que provável essa transposição da periodicidade cotidiana na escala maior daquela sazonal. 
Assim, o carão, a partir da sua crepuscularidade, leva-nos a níveis subentendidos de ambiguidade em que se exalta a capacidade de transitar entre diferentes zonas biogeográficas, épocas climáticas e modos de subsistência. Ele, enquanto pássaro crepuscular, palustre e caramujeiro, transita entre termos normalmente experimentados como adversos: noite-dia; água-terra; seco-úmido; carnívoro-herbívoro. É mister destacar que estas mediações não coincidem com as meras "bissetrizes" que marcam as equidistâncias - ou não lugares ontológicos - entre duas qualidades concorrentes do real. A imagem da realidade que nos oferecem as impurezas do carão é mais complexa, levando-nos a conceber um plano constituído por séries naturais que, delimitadas por termos antitéticos ou experiências opostas, descansam sobre eixos horizontais, pensados como continuum internamente viáveis. Nestes últimos, como acontece no crepúsculo, os confins conceituais são liquefeitos, deixando lugar a situações de contato e de sobreposição que admitem a passagem gradual de uma posição para outra. O carão, em síntese, não representa o simples híbrido da coruja com a anhuma, pois pode "ser", no seu atuar, tanto coruja como anhuma, além de uma combinação variável das duas.

Se o mito conta sobre a passagem da natureza à cultura, as ambiguidades do carão predispõem o pensamento para movimentos que percorrem o mesmo caminho, mas no sentido oposto; atualizam o paradoxo descrito nas Mitológicas (cf. Sztutman 2009:9-10), que vê os mitos ameríndios descreverem a passagem falando tanto de uma saída gloriosa do estado de natureza, em direção à aquisição da cultura pelos homens, quanto da necessidade de reverter suas trágicas consequências - a perda de comunicação entre os homens e os outros seres (animais, plantas e espíritos) - voltando a ela. Isto porque as mediações lógicas realizadas pelo carão, no âmbito da natureza, parecem dirigir-se à solução de contradições de ordem cultural que "incomodam" a sociedade kadiwéu. Com esta afirmação, evidentemente nos colocamos no seio da interpretação estruturalista, em que a característica principal do mito, diante de um problema, é a de pensá-lo como homólogo a outros problemas que surgem em outros planos (Lévi-Strauss \& Eribon 1990:179).

Com respeito ao eixo terra-água, devemos levar em conta que, antes de ancorar a própria existência em postos de saúde, escolas e estilos de vida sedentários, os membros desta sociedade guaicuru costumavam acompanhar "o fluxo e refluxo das águas do Paraguai que inundam o Pantanal durante cinco meses e voltam vagarosamente ao leito, arrastando atrás de si a caça e o caçador kadiwéu" (Ribeiro 1979:24). A vida era medida pelas estações: épocas secas, em que esses ameríndios fugiam da terra árida e desabitada, buscando a vida nos cursos de água maior; e épocas de chuva, em que eles 
se retiravam das planícies alagadas e buscavam abrigo no alto das elevações argilosas da região. Portanto, somos levados a pensar que o problema da diferenciação/composição da terra e da água seja um problema realmente interessante para os Kadiwéu.

Recentemente, Duran (2015) coletou vinte nomes e descrições de alguns dos padrões mais recorrentes daquela arte gráfica kadiwéu, cujo estilo, segundo Lévi-Strauss (1996:173), "é incomparável diante de quase tudo o que a América pré-colombiana nos legou [...]". De acordo com algumas mulheres da aldeia Alves de Barros, um destes padrões, escalonado e chamado niwécalad, "simboliza os índios que antigamente subiam e desciam os morros da terra kadiwéu, nas cheias e secas do Pantanal" (Duran 2015:55). Este subir-descer/entrar-sair, que prevê atravessamentos de terras e águas, representa uma possibilidade/necessidade que o carão personifica magnificamente por ser um pássaro liminar por excelência, adaptado a este bioma constituído principalmente por uma savana estépica periodicamente alagada. Efetivamente, o carão vive à margem dos rios e açudes, mas se entranha nos "campos alagados, onde caminha abertamente, entrando com frequência na água até o ventre" (Sick 1997:290), como o boi de sela, preferido pelos Kadiwéu ao cavalo, justamente por suportar melhor "as caminhadas extenuantes pelo pântano, muitas vezes mergulhado na água até o peito" (Lévi-Strauss 1996:171).

Passando a outro eixo deste segundo grupo de ambiguidades encarnadas pelo carão, já antecipamos que o modo deste pássaro comer o caramujo tem mais a ver com a maneira de abrir e engolir frutos de casca dura do que com qualquer prática venatória. Talvez a relação prática deste terceiro tipo de ambiguidade com a vida dos Kadiwéu fique mais clara associando os dois padrões dietéticos do carnivorismo e herbivorismo aos dois principais métodos de subsistência da economia tradicional deste povo, cujos membros viviam principalmente da caça ao cervo e ao veado e da coleta de cocos e palmitos (Ribeiro 1979:24). Assim, se a coruja representa a categoria complexa dos carnívoros-caçadores e a anhuma a dos herbívoros-coletores, o carão está inserido entre as duas, constituindo o ramo dúbio dos carnívoros-coletores.

Não podemos fechar esta parte sobre as projeções sociológicas dessa grande divisão ornitológica sem mencionar o fato de que todas as diferenças aqui destacadas, sejam elas naturais ou culturais, tendem a agrupar-se de modo a formar dois blocos. Tanto os fatos da natureza como as funções sociais são classificados a partir de um esquema dicotômico, que acaba associando-os à coruja (terra, carnivorismo, estação seca, caça) ou à anhuma (água, herbivorismo, estação chuvosa, coleta) ${ }_{1}^{3}$ isto também em função de relações 
que existem entre eles, e não só das que os ligam a uma mesma ave. É evidente, por exemplo, que há uma relação de dependência das atividades econômicas para com as estações. Ainda que isto possa soar banal, o italiano Guido Boggiani, aventureiro e aspirante a comerciante de couros, teve que chegar até Nalique, então principal aldeia kadiwéu, para descobri-lo; mau grado seu, no dia 28 de janeiro de 1892, conforme documenta no próprio diário pessoal (posteriormente publicado): "Ao que parece Sabino [cativo xamacoco, criado pelos Kadiwéu] nos contou lorotas sobre a possibilidade de se caçarem cervos agora. Esta não é a estação propícia, sendo a das chuvas, e o campo onde se dão as grandes caçadas dos Caduveo está presentemente quase todo inundado pelas águas [...]" (Boggiani 1945:113).

Diante destas considerações, é fácil abandonar-se ao alto rendimento intelectual do estruturalismo, que distingue no animismo um método de pensamento que funciona por meio da correlação metafórica de descontinuidades entre séries naturais e séries culturais pensadas como dois eixos horizontais paralelos, cujos pontos estão ligados, dois a dois, por relações de homologia (Lévi-Strauss 2010:263). Diversos vocábulos kadiwéu apresentam múltiplos significados que remetem a estes dois domínios da realidade, a natureza e a cultura, pensados analogicamente como mundos especulares: igoja, por exemplo, significa apunhalar, mas também bicar (Griffiths 2002:73). Em outro mito de diferenciação - desta vez dos animais - Gô-noêno-hôdi veste a pele do martim-pescador para apunhalar com uma rápida bicada uma grande cobra aquática, cuja gordura será distribuída, de maneira desigual, a todos os animais (Ribeiro 1979:110). Outro exemplo relativo ao mito que estamos analisando é representado pelo termo kadiwéu etagaga: usado para nomear a anhuma, corresponde ao plural de etaga, "pessoa que apanha ou busca água" (Griffiths 2002:49).

\section{Um pássaro trapaceiro e o homem-pássaro: o eixo vertical}

A cosmologia kadiwéu concebe uma série de mundos paralelos, separados e autônomos que, ao menos num sentido figurativo, aparecem-lhes como sobrepostos, pois a comunicação mítica entre eles acontece através de imprevistas ou conduzidas verticalizações. Também no mito em análise, séries naturais e culturais não se limitam a correr paralelamente, espelhando-se metaforicamente umas nas outras, já que o carão atravessa corporalmente estas duas porções do ser. Como acontece regularmente nas práticas xamânicas, os humanos do mundo de baixo e os habitantes do mundo de cima se encontram neste mito através da incorporação do outro e de seu ponto de vista. 
Antes de continuar, devemos lembrar que os Kadiwéu, além e apesar de enxergarem alguns animais e outras subjetividades que povoam o universo ("deuses" demiúrgicos, espíritos e mortos) como gente-que impõe as mesmas categorias e valores que os humanos sobre o real - atribuem-lhes pontos de vista diferentes do deles. Como argumenta Viveiros de Castro (1996:127), ilustrando o perspectivismo ameríndio, não estamos ante uma multiplicidade de representações sobre o mesmo mundo, já que "todos os seres veem ('representam') o mundo da mesma maneira - o que muda é o mundo que eles veem": os veados e os cervos que as almas dos mortos caçam, para nós humanos, são cupins (Ribeiro 1979:17); o que para as almas dos mortos é carne para comer, para nós são folhas vermelhas (:117); o que nós vemos como fezes de cachorro, para as onças é tabaco (:126), e assim por diante.

Uma das consequências mais consideráveis dessa dissociação visual é que cada ser, em condições normais, enxerga só a própria humanidade e a de seus congêneres. Não parece ousado presumir que tanto o demiurgo como a coruja e a anhuma não conseguiam encontrar os ladrões porque não podiam percebê-los como centros de intencionalidade, isto é, como sujeitos. $O$ carão, ao contrário, os viu porque assumiu o ponto de vista deles; uma aquisição extraordinária, facilitada por outra classe de ambiguidade relativa que conecta e medeia a oposição natureza-cultura - a oposição entre naturezas diferentes dentro de um quadro cultural unitário, nos termos não antropocêntricos do perspectivismo ameríndio. O carão corta perpendicularmente os andares do cosmo kadiwéu, e o faz misturando sua própria natureza com a dos humanos. Com efeito, parece ter alguma conexão fisio-lógica entre o carão ser o único a avistar aqueles ladrões proto-humanos de peixe e o fato de outro pássaro mitológico, o carcará, ter jogado cinzas ${ }^{4}$ dentro da panela em que o demiurgo estava preparando o caramujo para ele: "Gô-noêno-hôdi tinha dado caramujo para o carão comer, mas o Caracará botou cinza nos caramujos, por isso é que caramujo não tem gordura. Assim mesmo o carão ficou olhando e cantando [...]" (Ribeiro 1979:104).

O carcará (Polyborus plancus), espécie de ave de rapina da família dos falconídeos, é outro personagem dúbio de primeira importância no panteão kadiwéu, sendo intérprete de uma ambiguidade mitologicamente mais explícita, basicamente moral, embora sempre acompanhada pelo seu reflexo fisiológico e comportamental, já que estamos falando de um predador e carniceiro ao mesmo tempo. Companheiro e astuto conselheiro do ingênuo demiurgo, o carcará é promotor, simultaneamente, de "desnecessárias" privações e de grandes transformações, como a descrita pelo mito aqui em análise. Justamente pelo fato de atuar ora em benefício dos homens, ora 
prejudicando-os, e de seus atos transparecerem certa malícia, malevolência e sobretudo ambiguidade, o carcará é incluído por Darcy Ribeiro (1979:56) na categoria do trickster, o "pregador de peças" que povoa muitas mitologias ameríndias.

A transformação que as cinzas produziram no caramujo - "por isso é que caramujo não tem gordura" (Ribeiro 1979:104), nem "mais gosto nenhum" (Siqueira Jr. 1993, Anexo 2:9) - sugere que se tratava de brasas que cozinharam o caracol. O carão, através da apropriação metonímica (consequência pela causa) do fogo de cozinha, prerrogativa exclusiva dos humanos, transforma-se num deles. ${ }^{5}$ Que a diferença entre os pontos de vista específicos seja dada pela diversidade dos corpos - não de sua fisiologia, como adverte Viveiros de Castro (1996:128), mas dos afetos, afecções ou capacidades que singularizam cada espécie de corpo (o que ele come, como se move, como se comunica, onde vive, se é gregário ou solitário etc.) - infere-se, justamente, do fato de que é pelo corpo que esta pode ser (temporariamente) "anulada"; é pelo corpo, sua manipulação metamórfica, que o membro de uma espécie pode assumir o ponto de vista de outra espécie - ou, dependendo dos casos, ser "engolido" por ele.

Em relação a este segundo caso, entre os Kadiwéu está bastante claro que quem adota um comportamento próprio do "inventário" de outra espécie pode acabar assumindo o seu ponto de vista, pagando, entretanto, um preço muito alto: a perda de sua própria perspectiva específica, quer dizer, a perda da (sua) humanidade. O xamã João Gordo, conforme conta a Ribeiro (1979:213-214), teve que rejeitar os repetidos convites de uma onça para comer uma anta recém-caçada. O perigo do qual ele fugia era o de tornar-se definitivamente uma gente-onça. Na vida cotidiana kadiwéu, abundam as restrições alimentares que servem para evitar que o humano - sobretudo quando transita pelos interstícios da vida social - se torne animal. Essa transformação sem retorno é o motivo recorrente dos mitos de origem das estrelas, pois uma vez crianças desobedientes, homens preguiçosos ou velhos saudosos que, por ficarem acordados à noite - o "dia" de muitas entidades não humanas - e à margem da socialidade humana, foram arrastados para o céu por "certos entes notívagos, ora chamados cipós, ora bichos" (Ribeiro 1979:48). Economias descontroladas da corporalidade estariam também nas origens da maior parte das doenças, o que os Kadiwéu explicam pela teoria da intrusão ${ }^{6}$ (Ribeiro 1979:221) no corpo do paciente de espíritos e bichos $^{7}-$ e suas perspectivas.

Contudo, como ilustram os acontecimentos míticos aqui tratados, essas transformações fatalmente irreversíveis possuem um avesso épico extremamente proveitoso; o de certos indivíduos como o carão ou os xamãs 
- cada mundo tem os seus: veja-se o porco-xamã dos Juruna (Lima 1996) - que têm a habilidade de cruzar as barreiras corporais entre as espécies e adotar a perspectiva de subjetividades "estrangeiras", de modo a administrar as relações entre estas e a própria (Viveiros de Castro 2015:49). Sobretudo, "eles são capazes de voltar para contar a história" (:49). Os grandes benefícios e as terríveis desgraças que promete a metamorfose interespecífica levam os xamãs e os "leigos" do povo kadiwéu a se sentirem constantemente suspendidos entre o desejo e o terror de "virar bichos". Se o encontro-intercâmbio de perspectivas é desenvolvido através de um apropriado diálogo transespecífico - verdadeira arte política (:49) - este pode trazer grandes benefícios. De outro modo, ele causará alguma infausta fatalidade que, com toda a probabilidade, levará à morte. É na linha tênue entre estas duas extremas possibilidades que ocorre o memorável duelo mítico entre o prestigioso xamã Ipéke-liwilã (pele sobre os ossos) e outro xamã seu inimigo, informado por Ribeiro (1979:126-127), em que cada um deles, a seu turno, chamava um bicho e o dava para o outro engolir para ver se seu oponente assimilava a sua força ou era irremediavelmente aniquilado por ela.

A identificação dos benefícios que os mediadores de cada mundo trazem para a própria espécie não é tarefa simples. Primeiramente, num plano puramente filosófico, a assunção da perspectiva de outras espécies de seres envolveria a possibilidade de alcançar uma melhor compreensão do universo e das inumeráveis subjetividades que estariam atrás de quase todos os fenômenos - "o quem das coisas" (Viveiros de Castro 2015:50). Entretanto, geralmente o impulso teórico é parte integrante de uma instância operativa que se dirige para a resolução de algum problema concreto. Dito de outra forma, a incorporação de perspectivas outras não envolve só a esfera do "ver", mas também a do "agir". O xamã que envergar a "roupa" de jaguar, por exemplo, não se limitará a conhecer o ponto de vista dele, mas o usará pragmaticamente: “Ele poderá por um tempo enxergar ou caçar como jaguar" (Calavia Sáez 2012:10).

Em particular, o perspectivismo kadiwéu parte da ideia de uma (possível) relação social entre humanos e "mundo natural" que não é contida por simples esquemas de identificação, baseados em uma interioridade compartilhada, conforme, por exemplo, a ontologia animista teorizada por Descola (2005). Isto porque as aparentes identificações com o outro introduzem sempre umas relações diferenciadoras. O objetivo dessa filosofia ameríndia da diferença (Sztutman 2009:9), ilustrada por Viveiros de Castro com a cumplicidade da filosofia deleuziana, não seria apenas identificar as semelhanças entre animais e humanos, mas sim reconhecer e usar as 
diferenças que aparecem nelas. Seja como for, não há dúvida de que, para os Kadiwéu, a possibilidade de ver simultaneamente segundo duas perspectivas incompatíveis envolve a assimilação de habilidades novas, além de ideias inéditas, consequência de uma dilatação extraespecífica das próprias inclinações teóricas e práticas.

Quando, por exemplo, Gô-noêno-hôdi afrontou a grande cobra vestido com a pele do martim-pescador (Ribeiro 1979:110), não estava estabelecendo uma mera relação metafórica entre um punhal e o bico do pássaro. Vale exatamente o contrário: a correlação entre o punhal e o bico do martim pescador lhe serviu para entender que só com este último, e a ligeira rapidez de seu "braço" plumado, teria tido alguma chance de alcançar o coração da cobra. E assim foi. Ou seja, o reconhecimento de que o bico dos pássaros e o punhal dos homens ocupam, em seus respectivos mundos, o mesmo lugar de "armas penetrantes" constitui só uma passagem no caminho que leva à utilização da "diferença de potencial" - noção usada por Hubert e Mauss (2003:154) na construção do conceito de mana - existente entre eles. É a busca dos poderes inerentes a este tipo de desigualdades - variante epistemológico-operacional daquela economia da alteridade predatória que, segundo os amazonistas, constitui o regime basal das socialidades ameríndias (Viveiros de Castro 2015:161) - que motiva os xamãs a atravessarem as barreiras específicas com todos os riscos que esse movimento comporta. Podemos, portanto, concluir que os humanos in fieri do mito de origem descobriram, pelo olhar do carão naquele ambiente paludícola, modos eficientes de organizar a própria vida em sociedade.

Como dito anteriormente, cada mundo tem seus xamãs. Se o carão enxergou uma humanidade ainda notívaga e oculta depois de ter ingerido o "seu" alimento do outro lado deste espelho viscoso em que se refletem e se apanham humanidades outras, antes de começar suas sessões, o xamã "se veste" de animal, empunhando em uma mão um penacho de ema e na outra, um chocalho e, às vezes, usando um adorno de penas na cabeça (Ribeiro 1979:227). Os espíritos descem pelo penacho (:244) que o xamã utiliza para curar os seus pacientes ou para matar os seus inimigos, para profetizar e controlar os elementos naturais. Em ambos os casos, nós nos encontramos diante de economias da corporalidade (Viveiros de Castro 2015:40), por meio das quais agentes intermediários intentam comunicar-se com naturezas outras, alcançáveis através de piscadelas que parecem encaminhar para uma comum ontologia primordial, da qual as espécies representariam sedimentações parciais.

Presumivelmente, é também por esta última razão que cada espécie recruta seus intermediários entre os mais ambíguos (ou menos "sedimen- 
tados") do próprio grupo. Se já falamos abundantemente das dubiedades do carão, poderíamos dedicar outras tantas reflexões à caracterização da figura do xamã, cuja vocação é descoberta através de doenças - "um estado intermediário entre a vida e a morte" (Lévi-Strauss 2004a:85) - sonhos e visões que marcam, ao mesmo tempo, a sua posição marginal em face da sociedade kadiwéu, e o seu caráter liminar em relação ao mundo dos espíritos. A ambiguidade mais manifesta é a moral, da qual os xamãs e o próprio carcará são portadores, oscilando eles entre dois polos: "O nidjienigi ou padre que serve fielmente à comunidade e usa seus poderes para protegê-la e o otxikonrigi ou feiticeiro ao qual se atribuem as mortes, as doenças e quase todas as infelicidades" (Ribeiro 1979:199).

Bichos e xamãs, de certa forma e em determinados momentos, participam de ambos os mundos que contribuem para comunicar, constituindo porteiros especularmente justapostos do mesmo umbral. O mais surpreendente é que, de qualquer parte que se observe tal passagem, a chave para aceder sem perigo ao outro lado é exatamente a mesma: o canto. Trata-se de um canto repetido, demorado e crepuscular. O carão "ficou a noite inteira cantando e olhando" (Ribeiro 1979:104), sendo que as duas ações são indissociáveis. Da mesma forma, o nidjienigi consegue invocar os bichos, entrando em êxtase, "depois de horas de canto repetitivo e monótono" (:225). Esse canto também é realizado à noite - "padre só canta à noite" (:223) - na penumbra de um fogo sem chamas (:222), cuja luz/sombra é suficiente para reativar o fluxo mítico, reduzindo as formas definidas ao estado de virtualidades para atualizar (Viveiros de Castro 2015:59).

A voz do carão é "forte e cheia, um grito longo frequentemente seguido por 3-4 gritos curtos, [...] no crepúsculo e à noite com demoradas repetições" (Sick 1997:290). De modo semelhante, o canto do nidjienigi, também realizado no escuro, intercala demoradas repetições e picos de intensidade em que o ritmo do maracá se faz mais excitado e os cantos atingem o máximo da força (Ribeiro 1979:237). O clímax alcançado por meio destas alterações de crescente dramaticidade corresponde, no mito, ao momento em que o carão vê os humanos - "estava quase amanhecendo e [...] cantou mais diferente" (Siqueira Jr. 1993, Anexo 2:9-10) - e, na sessão do xamã, quando este último chama "a chegada de seu bicho" (Ribeiro 1979:237). Nos crepúsculos dos respectivos mundos, o carão, conhecido também como "o pássaro que chora" (Palmer 1962), emite gemidos ou gritos humanos, enquanto o nidjienigi realiza, nas próprias sessões, jogos vocálicos e imitações dos animais invocados (Ribeiro 1979:226); ambos anunciando o nascimento de uma renovada personitude, potencializada pela assunção do ponto de vista de outrem. 


\section{0 poder da ambiguidade: juntando os eixos}

Tudo o que foi dito até agora nos mostra duas relações entre humanos e não humanos que ocorrem pela mediação de um mesmo personagem, o carão. A primeira, estática e simétrica - embora baseada na assimetria "moderna" (Latour 1994) de uma humanidade-sujeito que interage unilateralmente com uma natureza-objeto - apoia-se num carão que funciona como uma espécie de espelho, que devolve aos humanos que se refletem nele uma imagem mais nítida e detalhada das formas que habitam o cosmos e as suas mentes. Falamos de uma humanidade que toma como modelo a natureza, reconhecendo-se nela.

Na segunda relação, dinâmica e assimétrica - justamente porque reconstitui uma simetria política entre natureza e sociedade, suas alianças e trocas como um todo - a própria imagem reflexa assume os contornos de outro olhar; a superfície do espelho se liquefaz e é atravessada por agências, isto é, por forças orientadas, que fluem de um lado ao outro, como a compensar a diferença de potencial liberada pela abertura de um canal de comunicação interespecífica. Este segundo espelho, longe de representar apenas uma metáfora, aparece entre os instrumentos rituais de alguns xamãs kadiwéu. Um deles, João Gordo (Ribeiro 1979:223), profetizava as sortes da gente da própria aldeia, olhando através de um espelho para a gente que morava no campo do rio vermelho, no céu (os espíritos dos defuntos, provavelmente), no momento, é claro, em que estes últimos estavam olhando para baixo. Sabino, guia de Boggiani (1945:144) entre os Kadiwéu, fazia praticamente o mesmo com "um espelho enquadrado num pedação de pau".

Como começamos a ver, em nossas mãos, mais que duas relações, temos dois modos diferentes de ligar humanos e não humanos, em que não é difícil reconhecer as duas associações que, segundo o Lévi-Strauss do primeiro capítulo de O totemismo hoje (1976), os Ojibwa, ameríndios de língua algonquina, concebiam e praticavam entre humanos e animais. ${ }^{8}$ Por um lado, temos o "sistema totem" da anhuma e a coruja, que delimitam e constituem uma série natural de diferenças assumida como homóloga de uma paralela série cultural, de maneira que os Kadiwéu utilizariam a primeira para pensar metaforicamente na segunda. Por outro lado, temos o "sistema manido" que instaura uma relação, que não é de semelhança mas sim de contiguidade entre os progenitores do ser humano e o demiurgo "criador", isto é, entre dois domínios sociocosmológicos inicialmente separados.

Essa contiguidade não seria de caráter puramente religioso (ou seja, sociologicamente irrelevante) como defendia Lévi-Strauss, porque, como 
vimos, a capacidade de fazer dialogar perspectivas específicas diferentes "implica um modo de conhecer, ou antes, um certo ideal de conhecimento" (Viveiros de Castro 2015:50). O conhecer que decorre da assunção do ponto de vista de outra espécie constitui um modo epistemológico que só se tornou cientificamente admissível com a recente "virada ontológica" de nossa disciplina, e sua ideia de que, para compreender plenamente a visão do mundo dos povos "pré-modernos" (Latour 1994), é necessário aprofundar seus pressupostos ontológicos, bastante diferentes daqueles das modernas ciências sociais - que, por outro lado, precisam ser historicizados. Temos em nossas mãos dois modos de associar humanos e não humanos que, em última análise, constituem duas formas distintas de produzir conhecimento. O problema derradeiro é entender se elas colaboram e como.

Embora o objetivo principal do presente artigo seja o reconhecimento, no mito de origem kadiwéu, de duas relações humanos-não humanos, não podemos ignorar o fato de que estas nele convivem, coincidem na figura do carão e trabalham solidariamente. Portanto, não é possível evitar nos embrenharmos nessa ligação de relações mitológicas heteromorfas; e para começar a pensar nelas juntas, achamos ilustrativo partir do diagrama de O totemismo hoje, em que Lévi-Strauss (1976:119) representa o sistema "manido" e o sistema "totem" como perpendiculares um ao outro. Isto porque, como acontece no caso ojibwa, o plano das categorias kadiwéu do real parece constituir o degrau central de uma escada através da qual é possível passar de um mundo inferior, humano, ao mundo superior de um povo de cima, circulando pelos andares do mundo, quer dizer, por um mundo de andares, motivo recorrente nas mitologias chaquenhas (que Lévi-Strauss enquadra de diferentes ângulos em A oleira ciumenta [1986]).

Com efeito, se é pelo corpo que os habitantes do mundo de cima e do mundo de baixo trocam seus respectivos olhares, é no campo semântico dos conceitos e das categorias que essa troca se realiza; no reconhecimento das diferenças de significado ocultas dentro dos homônimos (o que para os mortos é carne para comer, para os vivos são folhas vermelhas), de correlações formais entre séries de termos (a oposição coruja-anhuma é análoga à de caçador-coletor) e das diferenças de potencial ocultas nos aparentes sinônimos (o bico e o punhal, nos mundos, respectivamente, dos bichos e dos humanos, têm o mesmo significado, mas cada um deles guarda valores e potências particulares de ordem específica). 


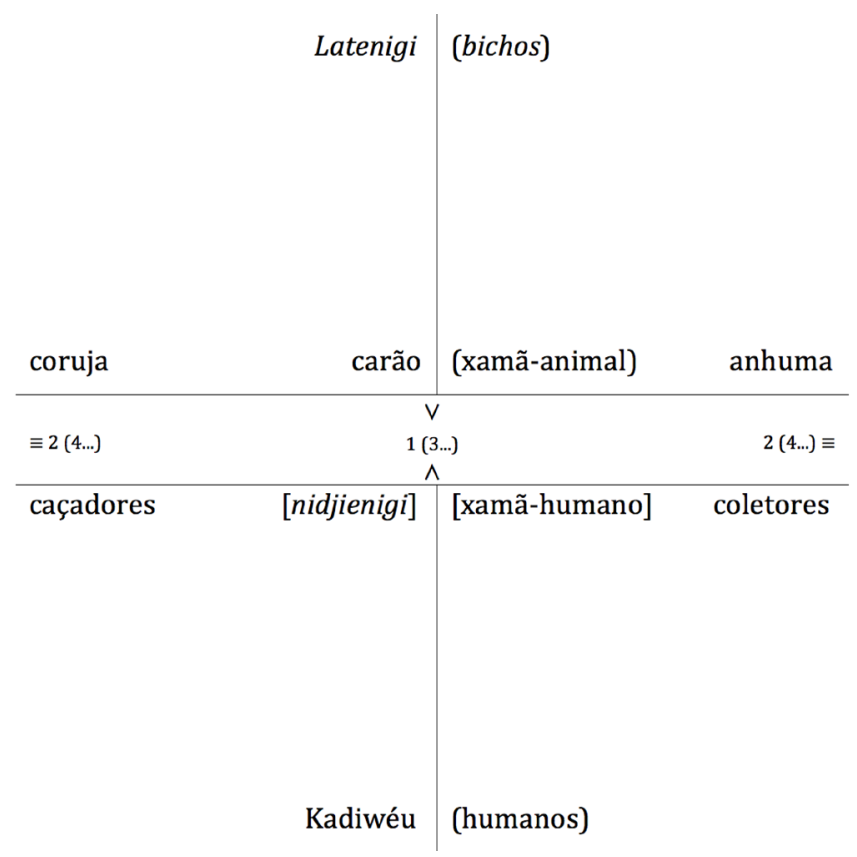

Entretanto, como podemos ver, para aplicar proveitosamente tal diagrama ao nosso caso de estudo e fazer dele o esquema de um suposto pensamento kadiwéu, tivemos que produzir algumas modificações no molde originário. Antes de mais nada, acrescentamos ao eixo horizontal da série natural (coruja-anhuma) o paralelo da série cultural (que para simplificar definimos: caçadores-coletores), ${ }^{9}$ pois nos interessamos pelo primeiro justamente pelas relações que projeta metaforicamente sobre o outro. Em segundo lugar, incorporamos ao esquema a lição fundamental de "A estrutura dos mitos", capítulo XI de Antropologia estrutural (1985): no mito, a correlação classificatória entre séries naturais e séries culturais é tornada operativa através da identificação de oposições inconciliáveis destas e de sua substituição por termos equivalentes daquelas que admitem um outro como intermediário. Ou seja, que o pensamento analógico natureza-cultura se torna verdadeiramente eloquente, capaz de formalizar e encarar questões e problemas sociológicos quando aplicado a pares de oposições do tipo que aqui estamos analisando: coruja : anhuma :: caçadores : coletores

São estas duas oposições que são comparadas pelo mito de origem kadiwéu e que é preciso aqui expor. Deste modo, o eixo horizontal deixa de representar uma simples lista de espécies naturais mitologicamente relevantes - isto é, de índices de equivalências natureza-cultura - para ilustrar uma relação interna de oposição/mediação que opera em dois planos diferentes. Os termos de cada uma das duas séries paralelas que compõem o 
desdobrado eixo horizontal não olham só para seus análogos, dentro de uma relação homomórfica global, mas definem suas relações recíprocas e sua distância, ao mesmo tempo em que diluem esta última, fazendo-a transitável. O eixo horizontal ganha, assim, um centro (o carão) que não é só gráfico; ele marca o lugar da resolução, por mediação lógica, de contradições que surgem na experiência de classificação do real.

Passando ao eixo vertical, o das relações interespecíficas reais, este deixará de se apresentar sob a forma de panteão hierarquizado, já que o mito representa o esforço de dois mundos (cada um com suas hierarquias, sua organização interna e seus emissários), inicialmente separados, para entrar em contato. Isto posto, o eixo vertical constituiria uma escada que conecta mundos justapostos e que, como notou o próprio Lévi-Strauss (2010:263), distinguindo entre sacrifício expiatório e sacrifício de comunhão, pode se percorrer nos dois sentidos. É só para destacar como cada mundo tem seus pontoneiros que acrescentamos a nosso esquema a figura do xamã, apesar de ele não aparecer (pelo menos de forma explícita) no relato em questão.

É claro que esta revisitação do diagrama de Lévi-Strauss é produto de um diálogo entre o estruturalismo, o perspectivismo e a mitologia kadiwéu que, em particular, nos leva a conceber as correlações "totêmicas" como dadas, não entre sujeitos (humanos) e objetos (naturais), mas entre sujeitos dotados de pontos de vista diferentes ou, para dizê-lo à la Latour (1994:120), entre classes distintas de sujeitos-objetos, ou sociedades-naturezas. ${ }^{10}$ Se o estruturalismo entendia os eixos que, para simplificar, chamamos de coruja-anhuma e caçadores-coletores como dois sistemas de diferenças globalmente e invariavelmente isomórficas, introduzindo a presença do outro (essencialmente no lado "natural" do eixo vertical), somos levados a considerar a correlação lógica que eles estabelecem (representada, no diagrama, pelo símbolo matemático de congruência: $\equiv)$ como resultado contingente e transitório do encontro entre embaixadores de mundos e humanidades distintas (que ilustramos com duas setas convergentes, no centro do diagrama), ou seja, entre perspectivas, entendidas não como cosmovisões permanentes e imutáveis - olhares fixos sobre o cosmos - mas como modos de inscrição e de descrição (Viveiros de Castro 2015:117). É por isso que numeramos com um este último movimento e com dois o primeiro, representando sua relação sequencial.

O mito de origem kadiwéu, portanto, representaria a estabilização histórica de uma relação real, cujo desenvolvimento, sendo ela sempre simétrica - nos sentidos que Latour (1994) dá a estas noções - é impossível predizer. Porque o outro, apesar de ser e de ver como nós, compartilhando conosco uma mesma "alma", possui caraterísticas específicas que lhe atribuem qualidades e habilidades que nós não temos e que não podemos prever. Ele, 
mesmo pensando como nós, vê coisas que nós não vemos e faz coisas que nós não sabemos fazer, e vice-versa. Logo, cada encontro, em princípio, é uma incógnita, assim como seus reflexos no eixo horizontal, das classificações da realidade empírica, de cada um dos atores envolvidos. A grandeza epistemológica e operacional dos diálogos transespecíficos residiria, justamente, na possibilidade de aceder a este "algo a mais" que emerge de um tipo de identificação espúrio, que diferencia.

Como assinala Viveiros de Castro (2015:119-120) no capítulo VI de Metafísicas canibais (um dos seus textos mais deleuzianos), quando diferentes perspectivas específicas são ligadas por uma ação de síntese, elas experimentam um movimento de implicação recíproca que é assimétrico. Toda identificação entre humanos e não humanos "degenera" numa guinada, já que, na síntese de seus olhares, eles descobrem uma divergência; e esta acaba contaminando e redirecionando seu ponto de vista. ${ }^{11}$ Isto porque, no reconhecimento em outra espécie da própria humanidade, uns e outros (re) encontrariam outras formas de decliná-la - das quais foram privados pelo processo de especiação. O Kadiwéu que, por exemplo, chegasse a "identificar-se" com o carão e suas vicissitudes sazonais possivelmente não enxergaria na imagem dele outro "eu", mas "outro eu"; não outra imagem (mais clara) de si, mas outra possibilidade de ser "eu", dentro da própria natureza.

Voltando, então, ao carão, ele, diante do problema kadiwéu da autodeterminação, primeiramente e como todo xamã, agiria como relator "real" (:171-172) de perspectivas específicas, colocando em comunicação humanos e não humanos. Aproximaria, naquela escada entre mundos que é nosso eixo vertical, os Kadiwéu e os pássaros do Pantanal, numa zona franca (naturalmente ambígua) em que uns podem vestir a "roupa" dos outros, ocupando sua posição subjetiva e assumindo seu ponto de vista. Entretanto, tanto os humanos como os pássaros comparecem ao encontro trazendo aqueles que, no momento, são seus respectivos modos de entender e delimitar o problema (caçadores/coletores e coruja/anhuma). É nesta altura que o carão se torna também correlator formal ${ }^{12}$ de duas séries de diferenças paralelas, uma humana e outra não humana. E isto não só porque é ele que se aproxima dos humanos, tornando comunicantes suas respectivas disposições classificatórias, mas também e sobretudo porque estes, vestindo a "pele" dele, acedem "naturalmente" a seu modo de situar e resolver o problema que os atormenta, que é um problema certamente complexo: caçar ou coletar, ficar perto ou longe da água, fixos ou mudando de lugar?

Não é por acaso que o mito termina com uma resposta a estas questões, uma definição dos traços caraterísticos desse povo, designado para deslocar-se pelo Pantanal em busca dos recursos naturais necessários para sua sobre- 
vivência; destinado a ser, dependendo dos casos, ora coruja, ora anhuma: “Deus disse ao carancho [o carcará]: 'deixa eles irem andando por aí, onde eles souberem que tem fruta, onde eles souberem que tem carne de caça para comer, eles vão'" (Pechincha 1994:114).

Neste diálogo transespecífico, em suma, tudo se passa como se a imperscrutável malícia do carcará estabelecesse uma troca de perspectivas entre os Kadiwéu, com seus dilemas, e um animal, o carão, que não só possui a resposta para essas dúvidas, mas também "é" a resposta, ao encarná-la em sua relação mediadora com os termos opostos em que o problema é posto no "hemisfério natural". Como sintetiza bem Viveiros de Castro (2015:50), no xamanismo ameríndio, "conhecer é 'personificar', tomar o ponto de vista daquilo que deve ser conhecido". A importância extraordinária do carão, neste mito, está justamente na sua capacidade de administrar, de forma simultânea, o sistema "manido" e o sistema "totem" e de nos mostrar como estes podem constituir dois momentos de um mesmo estilo de interação teórica e prática com a realidade - especialmente com suas porções mais incertas.

A assunção do ponto de vista de outrem revela-se necessária para o estabelecimento de uma relação comparativa entre duas situações controversas (formalizadas através de uma contradição de termos), vividas em dois mundos paralelos. Se o alinhamento de perspectivas, no eixo vertical, parece preceder o acoplamento dos olhares específicos delas sobre uma "mesma" situação (representados pelos dois eixos horizontais), pode ser verdadeiro também o contrário. Isto porque, se, por um lado, a incorporação da perspectiva de outrem sobre uma determinada situação (movimento 1, no eixo vertical) envolve a possibilidade de pensar esta última em outros termos - equivalentes mas divergentes - (movimento 2, no eixo horizontal), por outro lado, essa reavaliação interespecífica das categorias específicas acaba transformando o ponto de vista dos próprios atores implicados, mudando as condições em que se darão possíveis encontros futuros (movimento 3, no eixo vertical) e seus desdobramentos classificatórios (movimento 4, no eixo horizontal); e assim por diante. Mais que de dois momentos sucessivos, tratar-se-ia de uma oscilação perpétua entre duas experiências distintas - distinguíveis e separáveis, no entanto, mais na teoria que na prática - que se retroalimentam mutuamente.

Nosso diagrama, infelizmente, não dá conta do dinamismo que caracterizaria este tipo de pensamento que, baseado em uma constante compenetração entre conexões e disjunções interespecíficas, gera cadeias de correspondências (humanas, dos pássaros, de outras entidades não humanas) sempre imperfeitas e por isso votadas à introdução de novas possibilidades (teóricas e operativas) e à geração de transformações.

Tudo isso nos leva a uns comentários conclusivos. Embora o mito conte a origem do ser humano no começo dos tempos, ele mostra também aos 
Kadiwéu uma via que pode levá-los periodicamente a "renascer" mais fortes e mais sábios - pela incorporação de pontos de vista não humanos (ou diversamente humanos). Na imagem de Gô-noêno-hôdi puxando pelo cabelo o primeiro homem, que emerge chorando das trevas telúricas da própria solidão existencial (Frič apud Loukotka 1933:260), é possível ver a representação de um parto; também porque, nesta versão do mito, Ninigo, filho de Gô-noêno-hôdi, golpeia a terra, transformando-a em mulher (Loukotka 1933:255). Entretanto, esta transposição se torna ainda mais plausível se consideramos o implícito sexual do ato de comer o caramujo, que precede a saída do primeiro homem do buraco: as velhas kadiwéu costumam advertir toda moça sobre o perigo que corre durante os banhos em comum, avisando, em particular, sobre a possível chegada do carcará, ou mais prosaicamente, de algum rapaz que "puxa ela pra dentro d'água e vai quebrar o caramujo dela bem longe" (Ribeiro 1980:66). Se a advertência das anciãs soa como uma inibição cultural de um ato natural, o mito adquire a forma de uma exortação positiva: a de penetrar e atravessar as barreiras corporais da própria natureza, para fecundá-las com o sêmen - no mito, a cinza jogada no caramujo pelo carcará - de outras declinações do ser, nos tempos e nos modos devidos.

A formação da humanidade relatada no mito não é definitiva, assim como a ruptura do hímen-caramujo não é permanente. Os limites naturais dos mundos pós-míticos tendem a reformar-se num tempo muito mais rápido do que aquele que caracteriza os cantos longamente repetidos que, com grande esforço, atravessam-nos, introduzindo-se, por um lado ou pelo outro, nas viscosidades das suas células menos desenvolvidas. Todavia, cada vez que um destes cantos alcança o céu escuro e as profundidades mais carregadas do ser, anuncia-se o nascimento de um novo dia e o de um novo mundo.

Recebido em 05 de junho de 2017

Aprovado em 11 de março de 2018

Francesco Romizi é doutor em Antropologia pela Universitat Rovira i Virgili, Tarragona, Espanha, e pós-doutorando no Programa de Pós-Graduação em Serviço Social e Política Social, Universidade Estadual de Londrina, Londrina/ PR, Brasil. E-mail: <francesco_romizi@msn.com> 


\section{Notas}

* Este artigo foi produzido no âmbito da pesquisa de pós-doutorado "Os processos de construção mítica da realidade dos cristãos Kadiwéu na Alves de Barros", desenvolvida no Programa de Pós-Graduação em Ciências Sociais da Universidade Estadual de Londrina e financiada pela Coordenação de Aperfeiçoamento de Pessoal de Nível Superior a quem deixo aqui registrado meu agradecimento. Agradeço também a Flávio Wiik pela supervisão e a Maria Raquel Duran, Messias Basques e os três pareceristas anônimos pelas valiosas leituras e sugestões ao texto.

1 Como ilustra bem Petschelies (2013), o encontro com o ecalailegi produziu um crescente transvazar de temas, contextos e tipos mitológicos que, num primeiro momento, parece mais assumir a forma de uma cristianização dos mitos nativos, para, posteriormente, deixar lugar a uma indigenização das crenças cristãs.

2 Armação de um estrado, geralmente uma grade de varas de madeira, sobre paus fixados no chão.

3 Os pássaros do mito de origem kadiwéu nos levariam, em suma, a um sistema de classificação dualista, até certo ponto análogo ao reconhecido por Durkheim e Mauss (1981) em algumas tribos australianas, sem levar-nos, por isso, à sua gênese social.

4 A relação do carcará, chamado também de Gavião-de-queimada, com os resíduos, às vezes vivos, do fogo remete ao fato de que ele costuma besuntar-se de cinza; tanto é que os caboclos cearenses dizem que "o caracará leva galhos ardentes que deixa cair para incendiar os campos secos" (Sick 1997:265). Esta relação causal aparece também nos comentários feitos pelos Kadiwéu sobre as causas inumanas dos incêndios em suas terras no período das secas.

$5 \mathrm{O}$ fogo, no âmbito das mitologias das terras baixas, representa um dos principais comutadores mitológicos que fazem da natureza e da cultura dois domínios homologáveis, ligados por uma relação de continuidade. À luz da metamorfose pírica do "cru ao cozido" e de suas decorrências enculturadoras podemos pensar em uma possível analogia entre três "cocções" que, no âmbito kadiwéu, tendem a sobrepor-se, contribuindo para a dissolução - por meio de permutações, comutações, substituições etc. - dos intervalos existentes entre a natureza e a cultura: a dos caramujos na panela do demiurgo, manipulada pelo carcará; a dos primeiros homens encontrados em um buraco, sob uma tampa de barro; a da cerâmica, isto é, do barro que adquire forma e beleza, ganhando "vida", após ser exposto ao fogo, às tinturas das argilas e ao grafismo.

6 Conforme informado por Messias Basques, numa comunicação pessoal, os Kadiwéu costumam relatar casos de "mau agouro", quando animais que deveriam circular apenas "no mato" aparecem no meio da aldeia ou perto das casas das pessoas, causando certa confusão entre os limites da vida dos humanos e daquilo destinado aos animais. 
7 Termo funcionalmente ambíguo, que pode se referir tanto a animais que são espíritos como a espíritos com forma animal.

8 Em O pensamento selvagem (2010:261-267) e O homem nu, Mitológicas 4 (2011:655), Lévi-Strauss substitui metonimicamente a oposição ojibwa sistema "totem"-sistema "manido" por outros pares de tipo progressivamente mais abrangente, a saber, totemismo-sacrifício e mito-rito. E, efetivamente, a relação do segundo tipo é a que domina nas práticas do xamanismo kadiwéu: o carão entra em contato com os ladrões justamente porque atua como o xamã quando invoca e incorpora seus bichos.

9 Basicamente, sobrepomos ao diagrama ortogonal de $O$ totemismo hoje a representação gráfica por meio da qual Lévi-Strauss (2010:263), em O pensamento selvagem, ilustra de maneira desagregada o sistema do totemismo.

10 Com efeito, se, por um lado, esta reconsideração da autoria das comparações "totêmicas" nos leva a uma subjetivação dos eixos horizontais, imputados a formas distintas de personitude, por outro lado, acabamos também objetivando o eixo vertical. O encontro entre outros que ele põe em cena não é protagonizado por sujeitos transcendentes, mas por sujeitos que mergulham na materialidade de corpos e naturezas que condicionam seu modo de ver as coisas.

11 Ressaltamos o fato de que as contaminações recíprocas produzidas pela troca de olhares interespecíficos não vão na direção de uma homogeneização - por hibridação - dos polos dessa relação. Isto porque as sugestões que cada espécie recebe de outra são assimiladas segundo os atributos da própria natureza a partir das diferenças extensivas introduzidas pela especiação (Viveiros de Castro 2015:58). Uma definição, um pouco hermética, do cenário cosmológico que acabamos de representar poderia ser a seguinte: uma série de mundos paralelos, cada um dos quais seguindo o seu curso, que muda lá onde eles se cruzam. Com efeito, os difíceis rendez-vous entre membros de espécies diferentes geram sempre um grande paradoxo: cada vez que um indivíduo, através da incorporação do outro, se debruça sobre o "caosmos" (Viveiros de Castro 2015:56) pré-cosmológico em que aprofundam todos os seres, ele não reconstitui uma unidade perdida, mas dá um passo a mais no processo de construção da própria natureza distintiva. Isto porque as forças originais que lá (re) encontra ele as impõe às suas próprias formas, modificando-as. Neste sentido, a comunicação interespecífica, com a aquisição de novas habilidades que ela envolve, constituiria um importante elemento propulsor no processo de especialização. O mito de origem kadiwéu nos conta também isto.

12 Ao falar de "relator" real e correlator formal, aproveitamos as demarcações que Viveiros de Castro traça na terceira parte de Metafísicas canibais, dedicada justamente a esta controvertida convivência de estilos religiosos (sempre ponderados na ordem do pensamento). 


\section{Referências bibliográficas}

ALMEIDA, Ronaldo de. 2006. "Tradução e mediação: missões transculturais entre grupos indígenas". In: P. Montero (org.), Deus na aldeia. São Paulo: Globo. pp. 277-304.

ARENAS, Pastor; PORINI, Gustavo. 2009. Las aves en la vida de los Tobas del oeste de la provincia de Formosa (Argentina). Asunción: Tiempo de Historia.

BOGGIANI, Guido. 1945. Os Caduveo. São Paulo: Livraria Martins Editora.

BUFF CHEVAlIER, Sonia Rosalie. 1982. "Alguns mitos dos Kadiwéu". Publicações do Museu Municipal de Paulínia, 22:1-10.

CALAVIA SÁEZ, Oscar. 2012. "Do perspectivismo ameríndio ao índio real". Campos, 13(2):7-23.

DESCOLA, Philippe. 2005. Par-delà nature et culture. Paris: Gallimard.

DURAN, Maria Raquel da Cruz. 2015. "Leituras antropológicas sobre a arte kadiwéu". Cadernos de Campo, 24:43-70.

2017. Padrões que conectam: o Godidigo e as redes de socialidade kadiwéu. Tese de Doutorado em Antropologia Social, Universidade de São Paulo.

DURKHEIM, Émile; Mauss, Marcel. 1981 [1903]. "Algumas formas primitivas de classificação". In: Marcel Mauss, Ensaios de sociologia. São Paulo: Perspectiva. pp. 399-455.

FRIČ, Alberto Vojtěch. 1912. "Onoenrgodi-Gott und Idole der Kad'uveo in Matto Grosso". In: Proceedings of the XVIII session, International Congress of Americanists. London. pp. 397-407. Mimeo.

GILL, Frank B.; Stokes F.J.; Stokes C.C. 1974. "Observations on the Horned Screamer". The Wilson Bulletin, LXXXVI(1):43-50.
GRIFFITHS, Glyn. 2002. Dicionário da língua Kadiwéu. Kadiwéu-português, português-kadiwéu. Cuiabá, MT: Summer Institute of Linguistics.

HUBERT, Henri; MAUSS, Marcel. 2003 [1950]. "Esboço de uma teoria geral da magia". In: Marcel Mauss, Sociologia e antropologia. São Paulo: Cosac Naify. pp. 47-181.

IHERING, Rodolpho von. 1940. Dicionários dos animais do Brasil. Brasília: Ed. Univ. Brasília.

INGOLD, Tim. 1995. "Humanidade e animalidade". Revista Brasileira de Ciências Sociais, 28:39-53.

LATOUR, Bruno. 1994 [1991]. Jamais fomos modernos. Rio de Janeiro: Editora 34.

LÉVI-STRAUSS, Claude. 1976 [1962]. "Totemismo hoje". In: Seleção de textos. São Paulo: Victor Civita. pp. 113-126.

. 1985 [1958]. Antropologia estrutural. Rio de Janeiro: Tempo Brasileiro. 1986 [1985]. A oleira ciumenta.

São Paulo: Editora Brasiliense. 1996 [1955]. Tristes trópicos. São

Paulo: Companhia das Letras. . 2004a [1964]. Mitológicas I: o cru e o cozido. São Paulo: Cosac Naify. 2004b [1967]. Mitológicas II: do mel às cinzas. São Paulo: Cosac Naify. . 2010 [1962]. O pensamento selvagem. Campinas: Papirus. . 2011 [1971]. Mitológicas IV: o homem nu. São Paulo: Cosac Naify. .; ERIBON, Didier. 1990 [1988]. De perto e de longe. Rio de Janeiro: Nova Fronteira.

LIMA, Tânia Stolze. 1996. "O dois e seu múltiplo: reflexões sobre o perspectivismo em uma cosmologia tupi". Mana. Estudos de Antropologia Social, 2(2):21-47. 
LOUKOTKA, Čestmír. 1933. "Nouvelle contribution à l'étude de la vie et du langage des Kaduveo". Journal de la Société des Américanistes de Paris, 25:251-277.

OBERG, Kalervo. 1949. The Terena and the Caduveo of Southern Mato Grosso, Brazil, Vol. 9: Publication of the Smithsonian Institution, Institute of Social Anthropology. Washington, D.C.: Government Printing Office.

PALMER, Ralph S. (org.). 1962. Handbook of North American birds. Vol.

1. New Haven, Connecticut: Yale University Press.

PECHINCHA, Mônica Thereza Soares. 1994. Histórias de admirar. Mito, rito e história kadiwéu. Dissertação de Mestrado em Antropologia Social, Universidade de Brasília.

PETSCHELIES, Erik. 2013. O carcará e Cristo. Transformação kadiwéu. Dissertação de Mestrado em Antropologia Social, Unicamp.

RIBEIRO, Darcy. 1979. Kadiwéu. Ensaios sobre o saber, o azar e a beleza. Petrópolis: Vozes.

. 1980. Uirá sai à procura de Deus: ensaio de etnologia e indigenismo. Rio de Janeiro: Paz e Terra.

RIVASSEAU, Emilio. 1941 [1936]. A vida dos índios guaycurús. Quinze dias nas suas aldeias (sul de Matto-Grosso). São Paulo: Companhia Editora Nacional.

SICK, Helmut. 1997. Ornitologia brasileira. Rio de Janeiro: Nova Fronteira. SIQUEIRA JR., Jaime. 1993. "Esse campo custou o sangue dos nossos avós". A construção do tempo e espaço kadiwéu. Dissertação de Mestrado em Antropologia Social, Universidade de São Paulo.

SZTUTMAN, Renato. 2009. "Natureza \& cultura, versão americanista. Um sobrevoo". Ponto Urbe, 3(3): 1-18.

VIVEIROS DE CASTRO, Eduardo. 1996. "Os pronomes cosmológicos e o perspectivismo ameríndio". Mana. Estudos de Antropologia Social, 2(2):115-144.

. 2004. "Exchanging perspectives: the transformation of objects into subjects in Amerindian ontologies. Common Knowledge, 10(3):463-484. 2015. Metafísicas canibais. Elementos para uma antropologia pós-estrutural. São Paulo: Cosac Naify. WILBERT, Johannes; SIMONEAU, Karin. 1989. Folk literature of the Caduveo indians. Los Angeles, Califórnia: UCLA Latin American Center Publications.

\section{Fontes dos desenhos}

IHERING, Rodolpho von. 1940. Dicionários dos animais do Brasil. Brasília: Ed. Univ. Brasília.

MARTINET, François Nicolas; Daubenton, Edme-Louis. 1765. Planches enluminées d'histoire naturelle.

NAUMANN, Johann Friedrich. 1899. Naturgeschichte der Vögel Mitteleuropas. Lipsia: Gera-Untermhaus, F.E. Köhler. 


\section{O CANTO DO CREPÚSCULO REFLEXÕES ORNITO- ANTROPOLÓGICAS SOBRE UM MITO DE ORIGEM KADIWÉU}

\section{Resumo}

Este trabalho surge do descobrimento, no mito de origem kadiwéu, de duas relações que envolvem humanos e pássaros. Uma é a existente entre os três pássaros-detetives convocados pelo demiurgo para encontrar os ladrões do seu peixe - os ancestrais do ser humano. A outra é aquela entre o pássaro carão, o único que conseguiu ver os ladrões - permitindo ao demiurgo encontrá-los e "humanizálos" - e estes últimos. Com respeito à primeira, partindo de uma leitura estruturalista, argumentamos como esses pássaros formam uma série natural de diferenças, por meio da qual os Kadiwéu pensam metaforicamente sobre uma controversa série cultural, assumida como homóloga. Passando à segunda, interpretamos a hipótese perspectivista, defendendo a tese de que o carão enxergou aquela proto-humanidade no momento em que vestiu a sua "roupa", ingerindo um alimento cozido. Na última parte do texto tentamos juntar estas duas relações para nos aproximarmos da armação do pensamento mítico deste povo ameríndio.

Palavras-chave: Mito de origem, Xamanismo, Kadiwéu, Estruturalismo, Perspectivismo

\section{TWILIGHT SINGING ORNITHO-ANTHROPOLOGICAL REFLECTIONS ON A KADIWÉU ORIGIN MYTH}

\section{Abstract}

This study discusses two relationships involving humans and birds, as narrated in the Kadiwéu origin myth. One of these relationships concerns the three detective birds, called by the demiurge to find the thieves of his fish - the ancestors of human beings. The other relationship involves the only bird that was able to see the thieves - allowing the demiurge to find and "humanize" them - and the thieves themselves. With regard to the first relationship, starting from a structuralist point of view, I argue that these birds form a natural series of differences used by the Kadiwéu to think metaphorically about a controversial cultural series that is assumed as homologous. Moving on to the second relationship, I interpret it through the perspectivist hypothesis, arguing that the limpkin saw the protohuman thieves at the moment when he put on their "clothing", after eating cooked food. Finally, we try to combine these two relationships in order to approach the framework of the mythical thought of this Amerindian people.

Key words: Origin Myth, Shamanism, Kadiwéu, Structuralism, Perspectivism 


\section{EL CANTO DEL CREPÚSCULO \\ REFLEXIONES ORNITO- \\ ANTROPOLÓGICAS SOBRE UN MITO \\ DE ORIGEN CADUVEO}

\section{Resumen}

Este trabajo surge del descubrimiento, en un mito de origen caduveo, de dos relaciones que envuelven a humanos y pájaros. Una es la existente entre los tres pájaros-detectives convocados por el demiurgo para encontrar a los ladrones de su pescado - los ancestrales del ser humano. La otra es la que existe entre el carao, el único pájaro que consiguió ver a los ladrones - permitiendo que el demiurgo los encontrara y "humanizara" - , y estos últimos. Con respecto a la primera, partiendo de una lectura estructuralista, argumentamos como esos pájaros forman una serie natural de diferencias, por medio de las cuales los caduveo piensan metafóricamente sobre una controvertida serie cultural, asumida como homóloga. Pasando a la segunda, interpretamos la hipótesis perspectivista, defendiendo la tesis de que el carao divisó aquella proto-humanidad en el momento en que vistió su "ropa", ingiriendo un alimento cocido. En la última parte del texto intentamos juntar estas dos relaciones para aproximarnos al armazón del pensamiento mítico de este pueblo amerindio.

Palabras clave: Mito de origen, Chamanismo, Caduveo, Estructuralismo, Perspectivismo. 